\title{
Editorial
}

\section{Variação terapêutica e ensino médico}

O que é possível ensinar aos nossos alunos e residentes? 0 que poderia ser duradouro o suficiente para justificar o mestre? Do que necessita o aluno para querer ao seu lado alguém experiente? A prática da neurologia, principalmente no que concerne às doenças cérebro-vasculares, vem ganhando um corpo de evidências cada vez mais consistente, conduzindo obrigatoriamente a uma reflexão do que ensinar. A linguagem da epidemiologia clínica necessita ser difundida, e independentemente de interesses, custos e preconceitos, nossos futuros médicos não escaparão às exigências de uma prática científica do diagnóstico e tratamento.

Aquele mestre que fazia de uma maneira muito própria, peculiar e sua parece não ter mais lugar no mundo médico. 0 mestre que agia e determinava os destinos de pacientes porque tinha convicções fundamentadas na sua vida e racionalidade particular passou a fazer parte dos experimentos da clínica. O avanço tecnológico e a difusão da clínica como ciência permitiu uma constante avaliação das posturas e decisões médicas. Argumentos baseados em autoridade foram progressivamente sendo desconsiderados e muito pouco tolerados, principalmente nos países desenvolvidos. Na medicina americana, pelo menos nos centros de excelência no atendimento (que nem sempre coincidem com os de pesquisa ou renomados pesquisadores), ocorre uma prática menos deificada da medicina. Os argumentos clínicos e o que ensejam à pesquisa são a moeda de troca no mercado do pensamento e atenção ao paciente. Já não se requer mentes excepcionais para praticar e fazer evoluir o conhecimento médico: um modo de pensar e fazer, prático e eficiente, vem dando conta da demanda clínica e científica. 0 trabalho a ser realizado é enorme! As ciências básicas e associadas apontam indicadores relevantes, mas o paradigma da reatividade idiossincrásica do corpo exige o experimento clínico. E o experimento clínico pode reacender chamas de outrora, ou condenar ao esquecimento vultosos investimentos em uma terapêutica.

0 aluno de medicina é aluno para toda a vida, e seus verdadeiros mestres deveriam ensiná-lo a aprender eternamente. 0 aluno levará do mestre a postura diante da medicina e paciente, o cuidado propedêutico e o bom senso terapêutico. 0 mestre se justifica pela dimensão do possível, pelo espectro do comparável e pela força de modelação tão necessárias ao psiquismo humano.

Quando o aluno se depara com a variação terapêutica não se lembrará de argumentos autoritários, mas da mão que o guiou para a melhor opção científica de tratamento.

Felizmente estamos assistindo a uma grande transformação na maneira de pensar clinicamente no Brasil, e apesar de algo atrasados em relação aos países desenvolvidos, muito tem sido implementado na assistência terapêutica ao paciente, motivo porque gostaria de parabenizar todos aqueles que estão se dedicando ao enorme trabalho de prover treinamento profissional, pesquisa e atendimento aos pacientes com "acidente vascular cerebral" em nosso país. Os excelentes trabalhos sobre trombólise no AVC publicados aqui na Revista Neurociências tem sido de grande utilidade para reflexões e ações de saúde neste importante campo epidemiológico e clínico que muito onera nosso país e faz sofrer nossos cidadãos.

Gilmar Fernandes do Prado 